ADAM PEREAKOWSKI

Uniwersytet Jagielloński

iD ORCID ID: 0000-0003-2514-7757
WŁA DZA I POLITYKA

W CZASACH NOWOŻYTNYCH DYPLOMACJA I SPRAWY WEWNĘTRZNE

\title{
Przed wyjazdem do Stambułu. Kilka uwag na temat przygotowania misji Stanisława Chomentowskiego, wojewody mazowieckiego, do Porty Ottomańskiej w 1712 roku
}

\author{
Before going to Constantinople. A few remarks on the preparation of \\ the diplomatic mission of Stanisław Chomentowski, the voivode of Masovia, \\ to the Ottoman Porte in 1712
}

0 tanisława Chomentowskiego (1673-1728), wojewodę mazowieckiego, późniejszego hetmana polnego koronnego można zaliczyć do jednego z najbardziej doświadczonych dyplomatów w czasie panowania Augusta II Wettyna. Co prawda starsza historiografia nie zawsze miała o nim najlepsze zdanie, w czym z pewnością swoje „zasługi” położył Władysław Konopczyński, podsumowując życie i działalność Chomentowskiego takimi oto słowami: „Typowy epigon czasów Sobieskiego, bez twórczego umysłu i bez wiary w Polskę, dość zresztą uczciwy i nader bogobojny, szczęśliwie przeżył swój wiek, nie doznawszy ani klęski, ani kompromitacji”. Słowa te niezbyt dobrze świadczą o kwalifikacjach Chomentowskiego, ale też bardzo dobrze wiemy, że Konopczyński kierował się w swoich sądach prywatnymi uprzedzeniami. Dotyczyło to w szczególności czasów saskich i nie miało potwierdzenia w źródłach ${ }^{2}$. Znacznie lepiej oceniał wojewodę mazowieckiego inny z zasłużonych historyków epoki saskiej Julian Bartoszewicz: „Z zawikłań tureckich wypłynęło poselstwo Chomentowskiego do Turcji w roku 1712 [...]. Wojewoda miał naprzód oświadczyć się

${ }^{1}$ W. Konopczyński, Chomentowski Stanistaw h. Lis (1673-1728), [w:] PSB, t. III, Kraków 1937, s. 414.

2 Szerzej na temat nieco wykoślawionego obrazu czasów saskich u W. Konopczyńskiego pisze A. Perłakowski, Obraz Rzeczypospolitej czasów saskich w twórczości historiograficznej Wtadystawa Konopczyńskiego, [w:] Katedra historii polskiej na Uniwersytecie Jagiellońskim - odniesienia, interpretacje, pamięć, red. K.K. Daszyk, T. Kargol, Kraków 2019, s. 203-230. 
ku Porcie z przyjaźnią, potem przekonać ją, że August jest królem polskim, jedynym i prawdziwym". Zdaniem Bartoszewicza o pozytywnym zakończeniu misji Chomentowskiego w Stambule zadecydowała jego cierpliwość, wytrwałość, nawet w obliczu aresztu domowego w Adrianopolu, a „odzyskawszy wpływy w dywanie jako minister, czynnie się Chomentowski przyczyniał do rozwinięcia misji polskich w Persji”’3.

Misja zlecona Chomentowskiemu przez sejm warszawski, obradujący w dniach 5-19 kwietnia 1712 r. nie była jedyną w jego życiu. Kilka lat później, w roku 1720, wyjechał do Rosji, tym razem z zadaniem zleconym przez sejm grodzieński z 1718 r. Jego poselstwo do Piotra I miało na celu skłonienie cara do wycofania z terenów Rzeczypospolitej wojsk rosyjskich, stacjonujących tam od pierwszej dekady XVIII w. Prośby te były zresztą mocno spóźnione, gdyż Piotr I już wcześniej rozpoczął wycofywanie swych sił, jednak - jak stwierdził trafnie Józef Andrzej Gierowski - „Jakkolwiek też Chomentowski w czasie swojego poselstwa niewiele uzyskał, wrócił wszakże do kraju pod wrażeniem przemian, jakie zaszły w Rosji pod rządami Piotra I, uważając za konieczną politykę zgody z potężnym sąsiadem”ł. Jest to konstatacja słuszna, gdyż od tej pory jesteśmy w stanie uważać go może nie za zwolennika opcji rosyjskiej, ale na pewno za człowieka, który nie przeciwstawiał się zbytnio umacnianiu wpływów carskich w Polsce.

Sejm warszawski w 1712 r. zdecydował na wysłanie Chomentowskiego do Turcji. Jak stwierdzono w konstytucji: „dla ponowienia y utwierdzenia traktatu wiecznego Karłowickiego destynowali, y naznaczyli, tak też legacyją w osobie jego authoritate

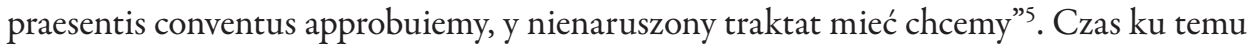
był najwyższy, bowiem klęska wojsk Karola XII pod Połtawą w lipcu 1709 r. bynajmniej nie uspokoiła sytuacji w Rzeczypospolitej. Co prawda August II już kilka tygodni po bitwie stanął w Polsce, gdzie specjalnym manifestem ogłosił nieważną swoją rezygnację z tronu podpisaną w 1706 r. w Altranstädt (zrzucając całą winę za nieprawną abdykację na posłów saskich Antona Albrechta Imhofa i Georga Ernesta Pfingstena negocjujących pokój altransztadzki), zawarł z carem traktat w Dreźnie, uzupełniając go znacznie gorszym porozumieniem podpisanym jesienią 1709 r. w Toruniu, jednak Stanisław Leszczyński nadal miał w kraju swoich zwolenników. Z kolei w Benderach na terytorium Księstwa Mołdawskiego, lennika Turcji, przebywał król szwedzki z resztkami swojej armii i polskimi adherentami (m.in. Józefem Potockim, wojewodą kijowskim czy Stanisławem Poniatowskim) prowadzącymi działalność dywersyjno-szpiegowsko-wywrotową na ziemiach polskich. Turcy po sukcesach militarnych i dyplomatycznych w Rosji (kapitulacja armii carskiej nad Prutem i traktat prucki w roku 1711, przedłużony

\footnotetext{
3 APE, ARB 906, s. 3.

${ }^{4}$ J.A. Gierowski, Dyplomacja polska doby saskiej (1699-1763), [w:] Historia dyplomacji polskiej, t. III (1572-1795), red. Z. Wójcik, Warszawa 1982, s. 372.

5 Volumina legum, wyd. J. Ohryzko, t. VI, Petersburg 1860, konstytucja „Legacya do dworów postronnych", s. 108.
} 
traktatem turecko-rosyjskim zawartym w Stambule 6 kwietnia 1712 r., w końcu potwierdzony pokojem w Adrianopolu w 1713 r.) i próbie ograniczenia wpływów rosyjskich w Rzeczypospolitej bacznie zwracali uwagę na wydarzenia w Polsce.

Napięcie między Rzecząpospolitą a Turcją szybko wzrastało, a potęgowały je zarówno działania dywersyjne stronników Leszczyńskiego, jak i złożona sytuacja wewnętrzna Rzeczypospolitej. Apogeum kryzysu nastąpiło w 1713 r., kiedy to wydawało się, że skoncentrowane na granicy z Polską wojska tureckie ruszą w głąb kraju. O kontekście politycznym kryzysu w stosunkach polsko-tureckich pisał 94 lata temu Józef Feldman w swoim klasycznym już studium o Polsce i tzw. sprawie wschodniej ${ }^{6}$. 10 lat później, także w kontekście misji Stanisława Chomentowskiego do Konstantynopola problem ten podjął Władysław Konopczyński, w swojej monografii zatytułowanej Polska a Turcja 1683-17927. Do dnia dzisiejszego jednak nie wiemy zbyt wiele o prowadzonej wtedy przez Portę Ottomańską polityce oraz o celach samego Stanisława Leszczyńskiego. Na pewno w jego planach było odzyskanie tronu polskiego przy pomocy wojsk tatarsko-tureckich. Temu zresztą służyły rokowania prowadzone przez jego adherentów z Turkami w Adrianopolu. August II, trzeba przyznać, potrafił skutecznie przeciwdziałać tym zabiegom, m.in. uwięził Jana Stanisława Jabłonowskiego, wojewodę ruskiego i wuja Leszczyńskiego, którego oskarżono o dążenie do wprowadzenia na tron swojego siostrzeńca oraz zapraszanie Turków do wkroczenia w granice Rzeczypospolitej. Jabłonowski przyznał się do spisku i zdrady, w konsekwencji uwięziony został w twierdzy w Königsteinie. W Gdańsku z kolei aresztowano żonę Józefa Potockiego - Wiktorię z Leszczyńskich, przy której znaleziono zaszyfrowane listy Leszczyńskiego. Zresztą dla Augusta II plany obozu antykróla nie były żadną tajemnicą, gdyż z polecenia Wettyna dokonywano regularnej perlustracji korespondencji Leszczyńskiego i jego zwolenników ${ }^{8}$. To, że do interwencji tureckiej nie doszło, spowodowane było wieloma czynnikami. Po pierwsze, Turcy nie zdołali zdobyć większego poparcia w samej Rzeczypospolitej dla sprawy Stanisława. Jedną z kluczowych decyzji była odmowa współdziałania z Portą obu hetmanów: wielkiego koronnego Adama Mikołaja Sieniawskiego i litewskiego Ludwika Konstantego Pocieja'. Po drugie, we wrześniu 1713 r. armia koronna, litewska oraz regimenty saskie skoncentrowane zostały między Brodami a Złoczowem, wyraźnie pokazując, że w razie potrzeby rozpoczną działania wojenne przeciw Turcji. Wzmocniono ponadto załogę oraz umocnienia Kamieńca Podolskiego i Okopów św. Trójcy. Widząc determinację ze strony polskiej, Apty Pasza, seraskier

${ }^{6}$ J. Feldman, Polska a sprawa wschodnia 1709-1714, Kraków 1926.

7 W. Konopczyński, Polska a Turcja 1683-1792, Warszawa 1936.

8 J.A. Gierowski, Nowe spojrzenie na geneze kryzysu politycznego w Rzeczypospolitej w 1713 roku, [w:] Na szlakach Rzeczypospolitej w nowożytnej Europie, red. A.K. Link-Lenczowski, Kraków 2008, s. 443-444.

9 Ibidem, s. 444-445. 
Benderu oraz Hachmer Ali Pasza, dowodzący wojskami tureckimi na pograniczu, zatrzymali się w Chocimiu, oskarżając jednocześnie Potockiego i Poniatowskiego o wprowadzenie strony tureckiej w błąd, gdyż mimo wcześniejszych obietnic, żaden ze zwolenników Leszczyńskiego ani też oddziały wojskowe wspierające antykróla nie pojawiły się nad Dniestrem lub Zbruczem ${ }^{10}$. Potocki wraz z Poniatowskim zostali aresztowani i odesłani do Benderu, a w rozmowach wysłanników tureckich z Sieniawskim zaczęły pojawiać się coraz wyraźniejsze tendencje ugodowe. Okazało się bowiem, że strona turecka nie zamierza wywoływać wojny, stoi na gruncie postanowień traktatu karłowickiego z 1699 r., życzy sobie dobrych stosunków z Polską, a w ogóle to wszystkiemu są winni stronnicy Leszczyńskiego, którzy przebywając na terytorium tureckim, knują i spiskują, nadużywając gościnności i dobroci sułtana oraz jego urzędników ${ }^{11}$.

Od tej pory groźba inwazji tureckiej zdecydowanie osłabła, a misja Stanisława Chomentowskiego miała na celu doprowadzić, może nie od razu, ale do odbudowania dobrych relacji polsko-tureckich. Niewątpliwie duże znaczenie miała też deklaracja strony cesarskiej, że w razie uderzenia Turcji na Rzeczpospolitą armia habsburska stanie po stronie Polski i udzieli jej wsparcia. Taką deklarację złożył Karol VI Habsburg ustami swojego posła w Konstantynopolu, Franza Anselma von Fleischmanna. Poparcia stronie polskiej udzielili też Piotr Szafirow, rezydent rosyjski w Stambule oraz Pierre Puchot baron des Alleures, ambasador francuski. Wsparcie dyplomaty Ludwika XIV Burbona nie było wówczas niczym zaskakującym. W tym czasie August II prowadził przecież rokowania na temat możliwości zawarcia traktatu z Francją, dzięki któremu mógł wyrwać się z izolacji na arenie dyplomatycznej.

Problem genezy i przebiegu kryzysu w stosunkach polsko-tureckich w 1713 r. był, jak już wspomniałem, przedmiotem omówienia dokonanego przez Feldmana i Konopczyńskiego oraz krótkiej wzmianki w książce Gierowskiego o Polsce i Lidze Północnej² I choć nadal nie mamy wyczerpującej w formie i treści monografii tego problemu, należy wspomnieć, że bardzo wiele interesujących ustaleń przyniosły badania Gierowskiego, który - opierając się przede wszystkim na źródłach watykańskich, głownie korespondencji nuncjusza Benedykta Odescalchiego Erby - rzucił nowe światło na tę kwestię. Okazało się bowiem, że wbrew temu, co dotychczas sądzono, Rzeczpospolita nie była bezbronna wobec zagrożenia tureckiego, potrafiła zmobilizować kilkanaście tysięcy wojska (razem z Sasami siły liczyły ok. 30 tys. żołnierzy), poza tym August II dobrze zareagował na to zagrożenie, neutralizując najważniejsze ośrodki opozycji w Rzeczypospolitej (przykład Jabłonowskiego).

Dyplomacja Stolicy Apostolskiej, w szczególności Odescalchi, posiadała, i nie jest to niczym specjalnie zaskakującym, dość dobre rozeznanie zarówno w kwestiach

\footnotetext{
10 Ibidem, s. 445-446.

${ }^{11}$ Ibidem, s. 446.

12 J.A. Gierowski, W cieniu Ligi Pótnocnej, Wrocław 1971, s. 148.
} 
międzynarodowych, jak i wewnętrznych Rzeczypospolitej. Na podstawie źródeł pozostawionych przed dyplomatów papieskich Gierowski opublikował kilka tekstów, które pozwoliły na zupełnie inne ujęcie problematyki polsko-tureckiej w tym czasie, właśnie z punktu widzenia polityki Rzymu ${ }^{13}$. Znajduje to zresztą potwierdzenie w wydanej dziewięć lat temu przez bp. Jana Kopca korespondencji dyplomatycznej Odescalchiego ${ }^{14}$. Z historiograficznego obowiązku wspomnieć również należy o niezwykle cennej, liczącej już 30 lat pracy rosyjskiego historyka Władimira Artamonowa o polityce Piotra I i samej Rzeczypospolitej względem Turcji, po zwycięstwie połtawskim, wyprawie pruckiej, aż do wydarzeń z roku $1714^{15}$. Bardzo ciekawe uwagi na temat polityki rosyjskiej od XVII aż do początku XVIII stulecia w kontekście planów rosyjskich i tureckich wobec Ukrainy Prawobrzeżnej przedstawił niedawno także Kirył Koczegarow ${ }^{16}$.

Analiza całej misji Stanisława Chomentowskiego do Porty Ottomańskiej w latach 1712-1714 jest zadaniem o tyleż atrakcyjnym, co niesłychanie trudnym, którego nie sposób pomieścić na kartach najbardziej nawet rozbudowanego artykułu. Jednocześnie temat ten jest swego rodzaju wyzwaniem badawczym, wymagającym nieco innego podejścia od klasycznych wzorców analizy działalności polskiej dyplomacji w epoce nowożytnej, a w czasach saskich w szczególności. Warto poświęcić nieco uwagi temu problemowi.

Nie jest tajemnicą, że przyzwyczailiśmy się do traktowania ówczesnej polityki zagranicznej Rzeczypospolitej, a dyplomacji w szczególności, jako swego rodzaju „produktu” o bardzo niskiej wartości, który nie mógł równać się z profesjonalną pod względem kompetencji i organizacji dyplomacją saską. Dlatego, co również często podkreślano, sascy dyplomaci podejmowali się w swoich działaniach reprezentowania, czy też obrony polskich interesów, zawsze jednak kładąc nacisk na to, aby na pierwszym planie realizować wolę i zamierzenia elektora. Obraz ten dopełniał fakt braku stałej rezydentury na obcych dworach, z wyjątkiem Stolicy Apostolskiej, gdzie interesy Augusta II i Rzeczypospolitej reprezentował Jakub Puchet. Na przeciwnym biegunie znajdowała się, o czym wspomniałem, dyplomacja saska, zbiurokratyzowana, lojalna wobec swojego

${ }^{13}$ Idem, Sejm w 1713 r. w relacjach nuncjusza Odescalchiego, [w:] Studia historyczno-prawne. Prace ofiarowane Kazimierzowi Orzechowskiemu w 70 rocznice urodzin, red. K. Matwijowski, S. Ochmann-Staniszewska, „Śląski Kwartalnik Historyczny Sobótka” 1993, nr 48, s. 259-266; idem, Stolica Apostolska wobec groźby tureckiego najazdu na Polskę w 1713 roku, [w:] Religia, edukacja, kultura. Księga pamiątkowa dedykowana Profesorowi Stanistawowi Litakowi, red. M. Surdacki, Lublin 2002, s. 97-108.

${ }_{14}$ Acta Nuntiaturae Polonae, t. XLIII (Benedictus Odescalchi-Erba [1711-1713]), vol. II (4 I 1713 - 17 I 1714), wyd. J. Kopiec, Kraków 2011.

15 V.A. Artamonov, Rossija i Riecz Pospolitaja posle Pottawskoj pobiedy (1709-1714 gg.), Moskwa 1990. Niestety nie mogłem skorzystać z najnowszego opracowania tego badacza. Por. V.A. Artamonov, Turecko-russkaja vojna 1710-1713, Moskwa 2019.

${ }^{16}$ K. Koczegarow, Polityka rosyjska wobec Rzeczypospolitej (lata 60. XVII wieku - początek XVIII wieku). Kwestia ukrainska, „Rocznik Instytutu Europy Środkowo-Wschodniej” 2016, nr 14, z. 2, s. 67-91. 
zwierzchnika, czyli elektora, zorganizowana (choć nie do końca) na wzór i podobieństwo dyplomacji Ludwika XIV ${ }^{17}$. Tymczasem poselstwo Chomentowskiego do Turcji pokazuje w nieco inny sposób sam przebieg misji dyplomatycznej. Było to, jak wiemy, poselstwo wysłane ma mocy decyzji sejmu walnego. Nie jest to nic zaskakującego, gdyż takie było prawo w Rzeczypospolitej. Krytycy zawsze zauważali, i niekiedy nie bez racji, że tego typu poselstwa nie były efektywne, gdyż brak stałej (polskiej) rezydentury na obcych dworach nie sprzyjał dobremu wypełnieniu misji. Czy była jednak to do końca prawda i czy - wyprzedzając nieco nasze rozważania - dyplomaci sascy i polscy działali zupełnie odrębnie od siebie, realizując zadania wyznaczone im z jednej strony przez elektora, a z drugiej przez powszechne zgromadzenie stanowe, jakim był polski sejm? Pytanie to jest jak najbardziej uzasadnione.

Nie ulega wątpliwości, o czym wspomniałem, że wyjazd Stanisława Chomentowskiego do Stambułu zasługuje na odrębną monografię. Przemawia za tym chociażby olbrzymia ilość źródeł pozostawionych z tych lat, począwszy od materiałów zgromadzonych w Archiwum Głównym Akt Dawnych w Warszawie (Archiwum Koronne Warszawskie, dział: Tureckie, „Księgi Poselstw” - „Libri Legationum”, dział V Archiwum Radziwiłłów), po liczne egzemplarze listów wojewody mazowieckiego zgromadzone m.in. w zbiorach Biblioteki Książąt Czartoryskich w Krakowie (korespondencja z Janem Szembekiem, kanclerzem wielkim koronnym, Adamem Mikołajem Sieniawskim i J.J. Przebendowskim, podskarbim wielkim koronnym) czy w Archiwum Narodowym w Krakowie (korespondencja z Jakubem Duninem, regentem kancelarii koronnej). Nie brak opisu przebiegu całego poselstwa, zarówno w wersji rękopiśmiennej ${ }^{18}$, jak i drukowanej oraz relacji z udzielonej Chomentowskiemu audiencji u wielkiego wezyra ${ }^{19}$. W 1732 r. w drukarni jezuickiej we Lwowie ukazało się drukiem dzieło zatytułowane Poselstwo wielkie Jaśnie Wielmożnego Stanistawa Chomentowskiego, wojewody mazowieckiego od Najjaśniejszego Augusta II. Króla Polskiego, Xiązecia Saskiego Elektora y Rzeczypospolitey do Achmeta IV tureckiego Wielkiego z petna moca Posta a szczęśliwym skutkiem przez lata 1712. 1713. 1714. Odprawione. Potomnych czasów pamięci wdzięczności podane przez X. Franciszka Gościeckiego Soc. Jesu.... 1734. Dzieło to jest w rzeczywistości panegirykiem, wierszowanym utworem literackim, zaopatrzonym w indeks

${ }_{17} \mathrm{~W}$ pewnym sensie fakt ten potwierdza analiza wettyńskiej dyplomacji z lat 1694-1697 podjęta dziewięć lat temu przez Judith Matzke. Por. J. Matzke, Gesandtschaftswesen und diplomatischer Dienst Sachsens 1694-1763, Leipzig 2011, Schriften zur sächsischen Geschichte und Volkskunde, Bd. XXXVI.

18 Rellacia z poselstwa do N. Porty Ottomańskiej Chomętowskiego wwdy maz., BCz, rkps 200/IV, s. 381-439. Por. inne wersje diariusza poselstwa: AGAD, AKW, DzT 79/572 i 79/572a; Relacyja z poselstwa do N. Porty Ottomańskiej Chomentowskiego, wwdy maz., B.Ossol., rkps 1477/III, s. 1-72; ANKr, ZZG 630, s. 1-4.

19 Relacyja audiencyjej JW JMP Chomentowskiego wdy mazowieckiego posta wielkiego od NJK Mci Augusta Wtórego i catej Rzptej do Porty Ottomańskiej u wezyra 10 7-bris 1713 miany, B.Ossol., rkps 1684/IV, s. 51-53. 
osób oraz indeks geograficzny. Stanowi pochwałę wielkości, przenikliwości, wreszcie skuteczności polityki Augusta II Wettyna i jej wykonawców, w tym przypadku Chomentowskiego jako posła króla oraz Rzeczypospolitej.

Przygotowania do poselstwa wojewody mazowieckiego trwały kilka miesięcy. Pod koniec maja 1712 r. na dwór doszła wiadomość o zawarciu pokoju między Rosją a Turcją. Informacja ta została odebrana z nadzieją jako dobra prognoza przed planowanym wyjazdem wojewody mazowieckiego. Jak wiemy, decyzja o wysłaniu wielkiego poselstwa do Stambułu zapadła w roku 1711 i nie było to również żadną tajemnicą dla strony tureckiej. W listopadzie tego samego roku Chomentowski w liście do Baltacı Mehmed Paszy, wielkiego wezyra wyjaśniał powody wysłania poselstwa:

dla utwierdzenia tak ścisłego przymierza, wiecznie karłowickim traktatem ugruntowanego wyprawuje mię tak Najjaśniejszy Król Jmć, jako też cała Rzplta w charakterze Wielkiego Poselstwa do tejże Porty Ottomańskiej. Gdzie da Bóg skuteczne dowody nienaruszonego pokoju i nieodmiennej niwczym przyjaźni od Najjaśniejszego Króla Jmci i całej Rzpltej reprezentować zechce $^{20}$.

Chomentowski otrzymał plenipotencje podpisane przez Augusta II w dniu 19 kwietnia roku $1712^{21}$. Dzień później kancelaria koronna wystawiła odpowiednią plenipotencję dla sekretarza poselstwa Adama Derengowskiego, wiceinstygatora koronnego ${ }^{22}$.

Misję Chomentowskiego poprzedziło wiele przygotowań o charakterze technicznym, wśród których na pewno wymienić trzeba „gotowanie” korespondencji przez hetmana wielkiego koronnego Sieniawskiego przeznaczonej dla dostojników tatarskich i tureckich. Ważne było również, o czym pisał Chomentowski we wspomnianym liście do wezyra:

abym zaś nie tylko tam według prawa Narodów wolny i bespieczny miał przejazd, ale też w ekspedyjowaniu tej mojej legacyjej łaskawie z powinnym honorowi mojemu respektem u Prześwietnej Porty był przyjęty proszę w tym o rzetelną Waszej Wezyrskiej Mci rezolucyją ${ }^{23}$.

Z taką samą prośbą zwócił się Chomentowski do seraskiera Sylistrii, oczekując przy okazji zagwarantowania bezpiecznego przejazdu dla siebie i swojego poselstwa ${ }^{24}$. Okazało się jednak, że już w czerwcu należało zmodyfikować treść tego dokumentu ze względu na to, iż Turcy podnieśli kwestię umożliwienia przez Rzeczpospolitą swobodnego

20 S. Chomentowski do Baltacı Mehmed Paszy, z Warszawy, 16 XI 1711, BCz, rkps 1687/IV, s. 497.

21 Plenipotencja dla S. Chomentowskiego, Warszawa, 19 IV 1712, BCz, rkps 610/IV, [bez paginacji]. Plenipotencję wystawił sekretarz pieczęci królewskiej Wilhelm Robertson.

22 Ibidem.

23 S. Chomentowski do Baltac1 Mehmed Paszy, z Warszawy, 16 XI 1711, BCz, rkps 1687/IV, s. 497.

24 S. Chomentowski do paszy sylistrijskiego, z Warszawy, 16 IX 1711, ibidem, s. 498. 
przejazdu zmierzającego do Szwecji Karola XII przez ziemie polskie ${ }^{25}$. Początkowo strona polska była zdecydowanie przeciwna tym propozycjom, jednak już w sierpniu 1712 r. Chomentowski otrzymał od Augusta II wyraźną sugestię: „abyś w rezolucyji tej propozycji wszelką pokazał łatwość" 26 .

Jak zwykle w takich wypadkach poważnym problemem były pieniądze. Jarosławska rada senatu obradująca w dniach od 6 do 8 czerwca 1711 r. na podstawie decyzji sejmu lubelskiego z 1703 r. zadecydowała o wysłaniu poselstw za granicę, nie wskazując jednak źródeł finansowania tego typu przedsięwzięć. Biorąc pod uwagę sytuację na terenach Rzeczypospolitej (dwuwładza, wojna domowa, okupacja szwedzka, przemarsze wojsk), nikt nie zaprzątał sobie tym głowy. Dopiero posejmowa warszawska rada senatu z 22 kwietnia 1712 r. wyznaczyła Chomentowskiemu wynagrodzenie w wysokości 50 tys. imperiałów (złotych), zaś dla sekretarza poselstwa zadeklarowano przekazanie pięciu tysięcy imperiałów ${ }^{27}$. Nie była to oczywiście pełna suma. Poza tym, decydując się na wysłanie poselstwa, senatorzy nie do końca orientowali się w możliwościach skarbu koronnego. Jeszcze w styczniu 1712 r., a więc na kilka miesięcy przed sejmem i posejmową radą senatu Chomentowski, wiedząc o tym, że uda się z misją do Stambułu, jednocześnie zdawał sobie sprawę, że będzie musiał zmierzyć się z problemami jej finansowania:

\begin{abstract}
Moja droga jeszcze się nie spieszy, bo gdy i od Turków i ja i Jmć Pan krakowski żadnej wiadomości nie mamy, ale też i Jmć Pan podskarbi dopiero pro 30 praesentis bydź ma, to choćby pieniądze zaraz oddał, o czym wątpię, to sprawunek mianowicie prezentów zabawi, czynię ja jednak co mogę z swego i wozy i konie i inne rzeczy z wolna sporządzam, aby omieszkania nie było ${ }^{28}$.
\end{abstract}

Co prawda wojewoda mazowiecki upewniany był przez Augusta II o przychylności i wsparciu królewskim, także od strony finansowej: „Cokolwiekby zaś Uprzejmość Wasza lub kredytu na tę drogę zaciągnął lub swoich własnych summ erogował, upewniamy Uprzejmość Waszę, iż się do tego szczerze przyłożemy, aby to skarb publiczny nieodwłocznie Uprzejmości Waszej bonifikował"29. Zarówno podskarbi Przebendowski, jak i sam Chomentowski zgodni byli co do tego, że 50 tys. złotych jest jedynie połową potrzebnej sumy ${ }^{30}$. Wojewoda mazowiecki uważał, że, biorąc pod uwagę bardzo

${ }_{25}$ August II do S. Chomentowskiego, z Drezna, 19 VI 1712, AGAD, AKW, DzT, 79/549, [bez paginacji]. nacji].

${ }^{26}$ August II do S. Chomentowskiego, z Międzyrzecza, 19 VIII 1712, ibidem, 79/550, [bez pagi-

27 Senatus consilium w Warszawie, 22 IV 1712, BCz, rkps 867/IV, s. 43.

${ }_{28}$ S. Chomentowski do J. Szembeka, z Turowa, 11 I 1712, ibidem, rkps 463/IV, s. 139.

29 August II do S. Chomentowskiego, [b.m.], 13 XI 1711, ibidem, rkps 613/IV, k. 141v.

30 J.J. Przebendowski do A.M. Sieniawskiego, [b.m. i d.], ok. XII 1711, ibidem, rkps 5925/III, n. 32571; J.J. Przebendowski do A.M. Sieniawskiego, z Warszawy, 2 VI 1712, ibidem, n. 32576. 
zły stan skarbu publicznego: „przykrzyć się nie będę jeżeli trzeba” ${ }^{31}$. Na ten cel (ekspedycję Chomentowskiego) podskarbi Przebendowski zmuszony był nawet zastawić swoje prywatne srebra w Gdańsku oraz zaciągnąć kredyt u kupców lwowskich ${ }^{32}$. Po przybyciu do Turcji poseł Rzeczypospolitej otrzymać miał drugą ratę pieniędzy ${ }^{33}$. Była to zresztą kwestia znana opinii publicznej, wspominały ją przecież krążące wśród szlachty gazety pisane $^{34}$. Tuż przed wyjazdem Przebendowski przekazal jeszcze kolejną sumę, tym razem 30 tys. dla Derengowskiego ${ }^{35}$. Sprawa sfinansowania poselstwa aktualna była przez najbliższe kilka lat. Aż do 1715 r. trwały rozliczenia Chomentowskiego ze skarbem koronnym za pieniądze wysyłane mu bezpośrednio z Rzeczypospolitej do Stambułu ${ }^{36}$.

Oprócz problemów z pustkami w skarbie koronnym, pojawiły się trudności w przekazaniu zwyczajowych podarunków, jakie poselstwo miało wręczyć sułtanowi oraz dostojnikom tureckim. Przebendowski zakupił je, a następnie zobowiązał Jakuba Zygmunta Rybińskiego, ówczesnego łowczego koronnego do ich przekazania Chomentowskiemu, na którego miały czekać we Lwowie. Okazało się jednak, że Rybiński tych upominków nie przekazał, mimo że zobowiązał się do tego na piśmie ${ }^{37}$. Z zachowanej listy podarunków dowiadujemy się, że upominki wojewoda mazowiecki miał przekazać w imieniu Augusta II sułtanowi, chanowi tatarskiemu i jego murzy. Dla sułtana przewidziano m.in. srebrną miednicę z nalewką, zegarek ze szczerego złota, bursztynową tabakierę, solniczki i lichtarze ze srebra. Władca krymski miał otrzymać srebrną karafkę z tacą, dwa zegarki (złoty i srebrny) i serwis z saskiej porcelany. Natomiast murza miał zostać „ukontentowany” srebrnymi serwisami, zegarkiem i tabakierą ${ }^{38}$. Oprócz tego poseł miał wręczyć gotówkę w wysokości 500 czerwonych zł dla sułtana, zaś drugie 500 czerwonych miało zostać rozdzielone między chana i murzę. We Lwowie Chomentowski odebrał również wyasygnowane przez Przebendowskiego pieniądze (25 tys. bitych talarów) ${ }^{39}$.

Przed wyjazdem uzyskano też deklarację hospodara mołdawskiego Mikołaja I Mavrocordata, który obiecał, wykorzystując listowne pośrednictwo Jerzego Bartscha, komendanta twierdzy kamienieckiej, użyczenie koni i ludzi, którzy mogliby służyć

${ }^{31}$ S. Chomentowski do J. Szembeka, z Zubrzy, 6 IX 1712, ibidem, rkps 464/IV, [bez paginacji].

32 J.J. Przebendowski do A.M. Sieniawskiego, z Warszawy, 9 VI 1712, ibidem, rkps 5925/III, n. 32577; J.J. Przebendowski do A.M. Sieniawskiego, z Warszawy, 11 VI 1712, n. 32578.

33 S. Chomentowski do J. Szembeka, [b.m.], 29 V 1712, ibidem, rkps 462/IV, s. 360.

34 „Z Krakowa 21 VI 1711”, APT, Gazety Polskie, nr 5-1711, k. 4v.

35 J.J. Przebendowski do A.M. Sieniawskiego, z Gdańska, 23 VII 1712, BCz, rkps 5925/III, n. 32581.

${ }^{36}$ Kwit Chomentowskiego potwierdzający odbiór 5 tys. tynfów, 28 VIII 1715, AGAG, ASK, dz. V, Księgi Kwitów 13, s. 315.

37 J.J. Przebendowski do A.M. Sieniawskiego, z Gdańska, 6 VIII 1712, BCz, rkps 5925/III, n. 32584.

38 Specificatia prezentów od JKM danych, ibidem, rkps 1687/IV, s. 189-190; spis w języku francuskim, AGAD, AKW, DzT, 79/551, [bez paginacji].

39 S. Chomentowski do J.J. Przebendowskiego, [b.m.], 1712, AGAD, AR, dz. V, 2115, s. 16. 
poselstwu niezbędną pomocą ${ }^{40}$. Na etapie przygotowań Chomentowski nie wiedział jeszcze, czy spotka się z hospodarem w stołecznych Jassach. Brano pod uwagę możliwość audiencji także w innym miejscu ${ }^{41}$. Na początku września $1712 \mathrm{r}$. wszystko było gotowe i Chomentowski mógł ruszyć w kierunku południowo-wschodnim. Razem z nim w drogę miał udać się murza tatarski, który po pierwszym noclegu wraz z zaufanym człowiekiem wojewody mazowieckiego winien odłączyć się od poselstwa i przygotować przejazd posła Rzeczypospolitej. W rzeczywistości chodziło o skłonienie Chomentowskiego do zmiany trasy poselstwa. Liczono, że poseł zechce spotkać się z chanem tatarskim Dewletem II Girejem, co Chomentowski skwitował krótko: „nie pozwalam, ale nie będę diffikultował, byle nie w Benderze, bo tam być absolute denego dla różnych przyczyn" ${ }^{\prime 2}$, pozostawiając sobie wolną rękę do dalszych negocjacji w sprawie ewentualnego spotkania z władcą krymskim. Tuż przed wyjazdem poważnie zachorował Derengowski. Obawiano się nawet jego śmierci, co postawiłoby pod znakiem zapytania całą misję, ale według Elżbiety Sieniawskiej wyleczył go Chevalier, nadworny lekarz Sieniawskich ${ }^{43}$.

Przygotowania do poselstwa odbywały się w cieniu ciągłego zagrożenia ze strony zwolenników Leszczyńskiego i resztek tzw. emigracji benderskiej. Jan Grudziński, starosta rawski, słynny „partyzant” Leszczyńskiego urządził w maju 1712 r. z Mołdawii rajd na tereny Rzeczypospolitej licząc, że uda mu się wzniecić powstanie przeciw Augustowi II ${ }^{44}$. Co prawda dotarł aż do Wielkopolski, a oddziały podległe Józefowi Potockiemu, innemu z wiernych zwolenników Stanisława, przejściowo nawet zajęły Śniatyń, lecz akcja ta nie zakończyła się powodzeniem. Koncentracja wojsk królewskich, hetmańskich i szlachty ziemi halickiej doprowadziła do rozbicia większości podjazdów ${ }^{45}$. Niebezpieczeństwo było jednak odczuwalne i to jeszcze podczas realizacji misji Chomentowskiego w samym Stambule ${ }^{46}$. Tuż przed wyjazdem wojewoda w obecności Sieniawskiego odbył konferencję z agą tureckim, o której treści miał zostać poinformowany

${ }^{40}$ S. Chomentowski do J. Szembeka, z Wielopola, 7 IX 1712, BCz, 4 rkps 64/IV, s. 351.

${ }^{41}$ S. Chomentowski do J.J. Przebendowskiego, z Jasienia, 29 V 1712, AGAD, AR, dz. V 2115, s. 11.

${ }^{42}$ S. Chomentowski do J. Szembeka, z Wielopola, 7 IX 1712, BCz, rkps 464/IV, s. 351.

${ }_{43}$ E. Sieniawska do A.M. Sieniawskiego, z Końskowoli, 15 VIII 1712, Korespondencja Elżbiety z Lubomirskich Sieniawskiej, kasztelanowej krakowskiej, t. I (Z serca kochająca żona i uniżona stuga. Listy Elżbiety z Lubomirskich Sieniawskiej do męża Adama Mikotaja Sieniawskiego z lat 1688-1726), oprac. i wyd. B. Popiołek, U. Kicińska A. Słaby, Warszawa-Bellerive-sur-Allier 2016, s. 309.

${ }^{44}$ W. Konopczyński, Polska a Turcja, s. 61; J. Wimmer, Grudziński Jan h. Grzymata (zm. 1735), [w:] PSB, t. IX, Wrocław-Warszawa-Kraków 1960-1961, s. 44.

45 S. Chomentowski do J.J. Przebendowskiego, z Jasienia, 1 VI 1712, AGAD, AR, dz. V, 2115, s. 12. Szerzej na temat wyprawy stanisławczyków pisze A. Perłakowski, Pogranicze polsko-motdawskie (tureckie) jako teren akcji dywersyjnych zwolenników Stanistawa Leszczyńskiego po Pottawie w świetle relacji regimentarza Aleksandra Krosnowskiego, [w:] Nad rzeka Kodyma. Studia nad dziejami polskich i ukrainskich pograniczy na przestrzeni wieków, red. T. Ciesielski, A. Korytko, W. Kusznir, Odessa 2018, s. 38.

46 S. Chomentowski do Augusta II, z Solca, 20 VIII 1714, BCz, rkps 464/IV, s. 257. 
także kanclerz Szembek ${ }^{47}$. Dość ciekawe stanowisko jeszcze przed oficjalnym rozpoczęciem misji dyplomatycznej zajął Chomentowski względem granic, których przebieg miał być ratyfikowany zgodnie z postanowieniami z Karłowic z 1699 r. Uważał bowiem, że skoro: „my nigdzie nie mamy do Czarnego Morza granic, boż hoc daretur przerżnęlibyśmy Krymowi z Turka kommunikacyją i z Budziakiem”", to strona polska podczas negocjacji mogłaby wysunąć pod adresem Turcji pewne (inne) roszczenia terytorialne.

O tym, w jaki sposób zrealizował wojewoda mazowiecki zadania wytyczone mu przez polski sejm możemy dowiedzieć się z materiałów pozostawionych przez samego Chomentowskiego: korespondencji z królem oraz ministrami. Moim zdaniem jednak nie możemy tak naprawdę mówić o poselstwie Chomentowskiego jako zjawisku odrębnym na zasadzie: wyjechał, przyjechał do Stambułu, załatwił (lub nie!) i wrócił. Musimy zdawać sobie sprawę z tego, że wyjazd Chomentowskiego do Konstantynopola jest wprawdzie ważnym, ale jedynie fragmentem większej operacji dyplomatycznej podjętej przez Augusta II, do której w pewnym momencie włączył się polski sejm. Mamy oto bowiem do czynienia z nieco wcześniejszą misją Joachima Franciszka Goltza, starosty śremskiego i pułkownika królewskiego oraz tajną misją Jana Spiegla do Porty w roku 1714. Te trzy wydarzenia są przedstawiane jako odrębne. Co prawda pisze się, że Chomentowski i Goltz mieli działać razem, ale już o misji Spiegla mieli niewielkie pojęcie ${ }^{49}$. Tymczasem sprawa nie jest do końca aż tak jasna i jednoznaczna. Uważam, że absolutnie nie można rozdzielać tych dwóch, a w zasadzie trzech poselstw. Misja Goltza przedstawiana jest jako misja królewska, na osobiste polecenie Augusta II, tymczasem mimo braku oficjalnych plenipotencji od polskiego sejmu, misję tę należy traktować jako wstępną i w pewnym sensie rozpoznawczą, mającą przygotować grunt pod oficjalne poselstwo od króla oraz Rzeczypospolitej, które następnie stało się udziałem Chomentowskiego. Na czym miało polegać owo przygotowanie? Z zachowanych źródeł (szyfrowanej korespondencji Goltza) wyłania się obraz bardzo skomplikowanej gry dyplomatycznej, prowadzonej w ciężkich warunkach (pamiętajmy o groźbie wojny polsko-tureckiej), czy

${ }^{47}$ S. Chomentowski do J. Szembeka, z Zubrzy, [b.d.] ibidem, [bez paginacji].

48 S. Chomentowski do J.J. Przebendowskiego, ze Lwowa, 14 IX 1712, AGAD, AR, dz. V, 2115, s. 14.

49 J.A. Gierowski, Dyplomacja polska, s. 448-449. Por. też obfitą korespondencję Goltza z okresu jego misji w Adrianopolu i Stambule w latach 1713-1714: BCz, rkps 694/IV, J.F. Goltz do J. Szembeka, z Adrianopola, 29 II 1713, s. 17-19; 23 IV 1713, s. 79-81; 10 V 1713, s. 73-77; 28 V 1713, s. 113-115; 21 VI 1713, s. 145-146; 29 VI 1713, s. 156; 2 VII 1713, s. 169-170; 8 VII 1713, s. 191-193; 19 VII 1713, s. 195-196; 22 VII 1713, s. 199; 26 VII 1713, s. 215-216; 30 VII 1713, s. 219; 2 VII 1713, s. 237-238; 8 VIII 1713, s. 245-246; 19 VIII 1713, s. 253-254; 10 IX 1713, s. 303-304; 10 X 1713, s. 369-374; 8 XI 1713, s. 419-421; 20 XI 1713, s. 431-435; 20 XI 1713, s. 439-442; 28 XI 1713, s. 455-459; 28 XII 1713, s. 485-491; ibidem, rkps 695/IV, z Konstantynopola, 17 I 1714, s. 9-11; 8 III 1714, s. 25-26; 15 III 1714, s. 41-44; 6 IV 1714, s. 52-59; 24 IV 1714, s. 61-62; 10 V 1714, s. 73-74; 20 VI 1714, s. 111-118; 29 VII 1714, s. 125-128; do Stanisława Szembeka biskupa kujawskiego, z Konstantynopola, 6 VIII 1714, s. 129-131; do J. Szembeka, z Konstantynopola, 25 VIII 1714, s. 137-139; 1 VIII 1714, s. 145-148. 
próby pozyskania sojuszników na terenie Turcji. O efektywności tych działań trudno mówić, skoro niemal zaraz po przybyciu do Porty Chomentowski trafił do pod straż - areszt domowy w Adrianopolu - i przez długi czas nie mógł działać zgodnie ze swoją instrukcją. W takim wypadku misja Goltza nabiera zupełnie innego znaczenia, o czym zresztą świadczą listy wysyłane do Sieniawskiego ${ }^{50}$. Bez aktywności Goltza trudno byłoby myśleć o pozytywnym zakończeniu poselstwa Chomentowskiego i odnowienia traktatu polsko-tureckiego oraz uznaniu postanowień karłowickich, co, jak wiemy, dokonało się w Konstantynopolu 22 kwietnia 1714 r. Goltz, działający jedynie w myśl instrukcji królewskich, przejął w pewnym momencie na siebie ciężar prowadzenia rokowań. Po zawarciu traktatu i odjeździe wojewody mazowieckiego nad Bosforem pozostał Spiegel. Jego zadaniem było „przypilnowanie” realizacji postanowień traktatu, szczególnie ze strony tureckiej. Turcy nie porzucili bowiem swojej wojennej retoryki, na szczęście tym razem skierowanej przeciw Wenecji, której wypowiedzieli wojnę 9 grudnia 1714 r. Mobilizacją sił i rozpoczęciem zbrojeń na szeroką skalę tłumaczyli też konieczność wzmacniania Chocimia, co powodowało słuszne zaniepokojenie polskiej strony i na długi czas było kością niezgody w kontaktach Sieniawskiego z pogranicznymi seraskierami.

Widać więc wyraźnie, że Goltz, Chomentowski i Spiegel nie działali osobno, ale w ramach jednej, poważnej inicjatywy dyplomatycznej, jaką było unormowanie bardzo napiętych stosunków polsko-tureckich. Co więcej, z zachowanej korespondencji Chomentowskiego - kiedy opuścił już Adrianopol - wiemy, że miał dobre rozeznanie w sprawie działalności Spiegla, a można nawet rzec, że w pewnym stopniu kontrolował jego poczynania przy pomocy sieci informatorów, którzy dostarczali mu nie tylko wiadomości o tym, co dzieje się w stolicy Imperium Ottomańskiego, ale również wieści o Spieglu. Polski dyplomata nie działał więc w próżni, a raczej starał się wykorzystać maksymalnie wszystko to, czym dysponował i na co mógł sobie w danej sytuacji pozwolić. Wprawdzie skala jego działalności nie była prowadzona aż z takim rozmachem, jak czynili to dyplomaci Francji, Rosji czy Cesarstwa, jednak można zaryzykować stwierdzenie, że nikt inny, znajdujący się na miejscu Chomentowskiego w Stambule, nie osiągnątby lepszych efektów.

Misja Chomentowskiego jest ważna jeszcze z innego punktu widzenia. W pewnym stopniu poddaje w wątpliwość tezę o atrofii polskiej służby dyplomatycznej. Okazało się, że dwór we współpracy z sejmem, a może mimo niego, przygotował poselstwo o dużym stopniu (jak na warunki polskie) profesjonalizmu. W krytycznym momencie był zastępca (Goltz), przypilnowano też wypełniania postanowień traktatu (Spiegel). Ale od początku do końca numerem jeden był Chomentowski, który nie stracił kontroli

\footnotetext{
${ }^{50}$ Listy J.F. Goltza do A.M. Sieniawskiego z lat 1712-1714, BCz, rkps 5818/III.
} 
nad rozwijającymi się wypadkami. Inna rzecz, że nie zawsze mógł im zapobiec. Z pewnością też w misji tej pomogło doświadczenie, jakie posiadali polscy posłowie od prawie 200 lat utrzymujący na różnym szczeblu kontakty dyplomatyczne z Portą.

Poselstwo Chomentowskiego należy ocenić jak najbardziej pozytywnie. Podporządkowanie Goltza i Spiegla jego działaniom miało swoje dobre strony. Uważam, że dyplomacja saska, mimo dużego stopnia profesjonalnej organizacji, wcale nie była efektywna. Co więcej, przerost biurokracji uwięził ją w gorsecie zawiłych procedur. Wystarczy prześledzić poczynania Augusta II wobec Tajnego Gabinetu w latach 1710-1719, aby zobaczyć, jak dalece ubezwłasnowolnił on pracę departamentu spraw zagranicznych. Narzucanie coraz większej ilości obowiązków, przede wszystkim sprawozdawczych, musiało odbić się na efektach pracy saskich dyplomatów ${ }^{51}$. Pisali oni niezliczone raporty, zestawienia, odbierali i wysyłali korespondencję, nie mając czasu na tzw. bieżącą działalność. Dla historyków wykonali potężną pracę, bo dzięki pozostawionym przez nich źródłom mamy co badać, ale z punktu widzenia ówczesnej polityki było to zgubne. Paradoksalnie to August II, wprowadzając wysoki stopień zbiurokratyzowania aparatu dyplomatycznego, był jednocześnie grabarzem jego skuteczności. Dopiero reformy lat dwudziestych, a później czterdziestych XVIII w. zmniejszyły nieco „papierkowe” obowiązki saskiej służby dyplomatycznej. Tym rygorom na szczęście nie podlegał Chomentowski w latach 1712-1714, więc istniała wtedy możliwość połączenia oraz współdziałania wszystkich, jakże ważnych wysłanników: polskich i elektorskich. Dało to efekt w postaci zawarcia traktatu i odsunięcia widma wojny z Turcją. A polska dyplomacja, jak się okazuje, mimo ogromnego kryzysu, któremu trudno zaprzeczyć, potrafiła wznieść się czasem na wyżyny swoich możliwości (przynajmniej proporcjonalne do ówczesnych) i z powodzeniem realizować postawione przed nią zadania.

${ }^{51}$ Pisze o tym szczegółowo J.A. Gierowski, omawiając działalność Tajnego Gabinetu. Por. J.A. Gierowski, Dyplomacja polska, s. 398-405. Jeśli chodzi o Tajny Gabinet, do dnia dzisiejszego aktualny pozostaje artykuł J. Dürichena, Geheimes Kabinett und Geheimer Rat unter der Regierung Augusts des Starken in den Jahren 1704-1720. Ihre Verfassung und politische Bedeutung, „Neues Archiv für Sächsische Geschichte und Altertumskunde" 1930, Nr. 51, s. 68-134. Por. ponadto rozważania W. Neugebauera, Monarchisches Kabinett und Geheimer Rat. Vergleichende Betrachtungen zur frühneuzeitlichen Verfassungsgeschichte in Österreich, Kursachsen und Preußen, „Der Staat” 1994, Nr. 33, H. 4, s. 511-535. 


\section{ANEKS}

Specificatia prezentów od JKMci danych, K. 1, BCz, 493/IV, s. 189-190; Les presents de la part du Roy [wersja w języku francuskim, bez paginacji], K. 2, AGAD, AKW, DzT 79/551.

[s. 189]

\section{Dla Chana}

Kaftyjerka srebrna pozłocista z tacą wielką takowąż

Zegarek sczerozłoty

Zegarek takowyż z repetitami

Serwis srebrny

Serwis z porcelany białej

Drugi serwis brunatny pozłocisty.

\section{Dla Murzy}

Nalewka wielka z miednicą srebrne

Garnuszek do the srebrny

Faierka srebrna

Dwie wielkie pozłociste srebrne tace

Dwa lichtarze srebrne, dwie solniczki i cukierniczka

Dzbanuszek na musztardę

Serwis srebrny ze 4. lichtarzami, 4. tacami dla codziennego używania

Dwa kociołki srebrne

Dwie flaszki na rataffią z czopkami

Flaszka srebrna na the

Zegarek sczerozłoty

Zegarek drugi princmetallowy pozłocisty z repetitami

6. tacek porcelanowych przednich z miseczkami

Dwie lulki porcelanowe

Tabakiera złota szmelcowana

Druga tabakiera z ambry w srebro oprawna

Czerwonych złotych in spetie 500.

\section{Dla Turczyna}

Miednica z nalewką srebrna

Zegarek sczerozłoty

Tabakiera bursztynowa ${ }^{a} \mathrm{w}^{\mathrm{a}}$ srebro oprawna [s. 190] 
Druga tabakiera $\mathrm{z}$ agarku w srebro oprawna

Dwa lichtarze srebrne

Dwie solniczki

Czerwonych złotych in specie 500.

a-a - nadpisane.

\begin{abstract}
The purpose of Stanisław Chomentowski's mission as the Grand Ambassador to the Sublime Porte in 1712-1714 was to confirm the terms of the Treaty of Karlowitz, signed in 1699, and to reduce the political tension between the Polish-Lithuanian Commonwealth and Turkey, which in late 1712 and throughout almost entire 1713 even threatened to erupt in an armed conflict between the two states. Considering the course of the mission, the difficulties in completing it, and even the temporary restriction of the Polish diplomat's freedom on the territory of the Ottoman state, its results should be regarded as definitely positive. Chomentowski's visit to Turkey, where he was supported by Augustus II's other diplomats, Franciszek Goltz (starosta of Śrem) and Jan Spiegel, resulted in averting the Turkish threat and renewing the terms of the Treaty of Karlowitz. The three missions, conducted by Chomentowski, Spiegel and Goltz, should be studied in the context of Augustus II's one large-scale diplomatic action, which ended successfully. It also proves that the work of the Polish diplomatic service in the times of the kings from the House of Wettin, about which historians, paradoxically, do not have a very high opinion to this day, was actually quite effective.
\end{abstract}

\title{
Keywords
}

Stanisław Chomentowski, Ottoman Porte, diplomatic mission 1712-1714. 